\title{
Hand and Wrist Injuries Among Collegiate Athletes Vary with Athlete Division
}

\author{
Kathleen Holoyda \\ University of Utah Health \\ Daniel Donato \\ University of Utah Health \\ David Magno-Padron ( David.magno@hsc.utah.edu ) \\ University of Utah https://orcid.org/0000-0001-6577-2413 \\ Andrew Simpson \\ University of Utah Health \\ Jayant Agarwal \\ University of Utah Health
}

\author{
Research Article \\ Keywords: Injury rates, Hand injuries, wrist injuries, NCAA, College, Division I, Division II, Division III \\ Posted Date: May 24th, 2021 \\ DOI: https://doi.org/10.21203/rs.3.rs-519733/v1 \\ License: () (1) This work is licensed under a Creative Commons Attribution 4.0 International License. Read Full License
}

Version of Record: A version of this preprint was published at Injury Epidemiology on December 1st, 2021. See the published version at https://doi.org/10.1186/s40621-021-00363-5. 


\section{Abstract}

Background: The rates, severity and consequences of hand and wrist injuries sustained by NCAA athletes are not well characterized. This study describes the epidemiology of hand and wrist injuries among collegiate athletes competing in different divisions.

Methods: The National Collegiate Athletic Association Injury Surveillance Program (NCAA-ISP) was accessed for various sports from 2004 to 2015. Data was stratified by hand and wrist injuries sustained, mean loss of activity time following the injury, male and female sport, need for surgery following injury and division. Descriptive statistics were performed to examine the association between sports, event type and gender. $\mathrm{P}<0.05$ was considered significant

Results 103,098 hand and wrist injuries were reported in all NCAA sports from 2004-2015. Male athletes sustained 72,423 injuries (6.01/10,000 athlete events) and female athletes sustained 30,675 injuries (4.13/10,000 athlete events). Division I athletes sustained significantly more injuries compared to divisions II and III. Overall, 3.78\% of hand and wrist injuries required surgical intervention. A significantly higher percentage of division I athletes (both male and female) underwent surgical intervention compared to divisions II and III. The mean time lost due to hand and wrist injury was 7.14 days for all athletes. Division I athletes tended to miss fewer days due to injury, though this was not significant.

Conclusions Hand and wrist injuries are common among collegiate athletes. Division I athletes sustain higher rates of injuries and higher surgical intervention rates, while tending to miss fewer days due to injury. Improved characterization of divisional differences in hand and wrist injuries can assist injury management and prevention

\section{Introduction}

More than 460,000 National Collegiate Athletic Association (NCAA) student athletes participate in 24 different sports every year.(1) During rigorous training and competition for up to forty hours per week, often with two practices per day, injuries can occur. Approximately $25 \%$ of all sport-related injuries involve the hand or wrist.(2-4) Despite the high incidence of these injuries, little is published regarding hand and wrist injuries sustained during collegiate athletics and how the injuries are managed.

As a part of its mandate to ensure the health and safety of student athletes, the NCAA has maintained a database of injuries during sporting events, including practice and competition, since 1982.(5) Since 2004, the Datalys Center for Sports Research and Prevention, Inc (Indianapolis, IN) began collecting and maintaining the Injury Surveillance Program (ISP) database based on reports filed by NCAA athletic trainers. Previous analysis of this database demonstrated the highest hand and wrist injury rates in men's and women's ice hockey.(6) Men were more likely to sustain hand and wrist injuries in NCAA sports and lose more time from their athletic activities compared to their female counterparts. Significantly more injuries occur during competition as opposed to practice due to the increased intensity and unpredictability of the competition setting.(6-9)

The rules of athletics are constantly changing to try to ensure the health and safety of collegiate student athletes. Some programs have eliminated two practices per day and new football helmets have been introduced in an attempt to decrease the incidence of concussion and traumatic brain injury in collegiate football players.(9) These safety precautions balance with the pressures on student athletes to perform within their respective sport. This pressure originates from coaches, teammates and personal pressure. Time missed due to injury can negatively affect the team dynamic. Many injuries to the hand and wrist may be minor, but more significant injuries require surgery and prolonged time away from participation in athletic events. Hand and wrist injuries may also lead to scholastic or employment impairment, making such injuries a significant concern for the student athlete.

The purpose of this study was to examine the epidemiology of hand and wrist injuries sustained by collegiate student athletes within the NCAA divisions based on information contained in a large national database. We specifically sought to compare injury rates sustained in each NCAA division, the severity and requirement for surgery within each division, and the impact of gender on these injury rates. We hypothesized that division I athletes would be more likely to sustain hand and wrist injuries, that division I athletes would miss the fewest days from participating in their sport, and that surgical intervention rates would be highest in division I athletes.

\section{Methods}

This study was deemed exempt from review by the Institutional Review Board on the basis of anonymous, de-identified information. The study protocol was reviewed and approved by the Datalys Center for Sports Injury and Prevention, Inc. (Indianapolis, IN) and by the NCAA.

\section{Database}


We queried the National Collegiate Athletic Association Injury Surveillance Program (NCAA-ISP) from 2004-2015. The database is composed of two different data sets, one from 2004-2009 and the second from 2010-2015. Both data sets contain slightly different variables, collection methods and participating teams.(10) The data set began in 2004 with the ISP collecting data on 15 core sports and adding further sports over time. Health information from male and female athletes from divisions I, II, and III was submitted by team athletic trainers from NCAA-sponsored teams. Club collegiate teams were not included in the database. Health information reported by the athletic trainers included athlete exposures and injuries. Exposures are defined as an organized team practice or competition that occurs during preseason, regular season or postseason. Athlete exposure (AE) refers to an individual athlete's participation in one of these exposures, either practice or competition. The injuries reported to the NCAA-ISP were sustained during an organized intercollegiate practice or competition and was identified by an athletic trainer or physician. Any injury sustained during activities outside an organized practice or event were not captured in the database.(10) Time loss is defined as an inability to participate in practice or competition that is measured in increments of days with a minimum duration of one day. The recording of non-time loss injuries is a notable difference between the two eras of the dataset such that the recording of these injuries began in the later era. This change was uniform across all divisions and genders, so this change should not affect the findings of the study. The two subsets have been combined in similar analyses previously.(6, 10, 11)

\section{Study Design}

We performed a retrospective, epidemiological cross-sectional analysis of hand and wrist injuries using information from the 2004-2015 database. We separated injuries by male and female athletics, as well as by NCAA division. The men sports included baseball, basketball, football, ice hockey,

lacrosse, soccer, and wrestling. The women sports included basketball, field hockey, gymnastics, ice hockey, lacrosse, soccer, softball, and volleyball. We included all hand and wrist injuries provided in the sample, however, we did not include fractures of the distal radius and ulnar styloid in our analysis as the ISP does not accurately differentiate between proximal or distal location of forearm bone fractures. All athlete exposures are assigned a unique identifier that included the year of injury, sport, and collegiate division. Of note, multiple injuries per student athlete were possible and included within the same unique identifier, however, it is not possible to determine the etiology of the different injuries.

In order to simplify data analysis, we categorized injuries into fractures and dislocations, and soft tissue injuries. The five categories for fractures and dislocations include: Dislocation-phalanx, phalangeal fracture, metacarpal fracture, scaphoid fracture and other carpal fracture. The 11 soft tissue categories include: Ligamentous injury - phalanx, ligamentous injury - triangular fibrocartilaginous complex (TFCC) /Distal radioulnar joint (DRUJ) /Scapholunate, ligamentous injury - other/wrist sprain, contusion - hand/finger, contusion - wrist, Tendon - phalanx, Tendon - wrist, wrist tenosynovitis, infection, nailbed, soft tissue injury - other.

\section{Statistical Analysis}

The data presented in the manuscript is representative of weighted, national estimates. The ISP provides the data with associated weights for each event in each sport and division. This weighting allows the data to be interpreted as national estimates based on the convenience sample of schools, sports and events, as reported by the athletic trainers. The sample weight calculation was based on the following formula: Weight $\mathrm{ijk}_{\mathrm{ijk}}=\left(\#\right.$ ISS Schools $_{\mathrm{ijk}} /$ \# sponsoring schools $\mathrm{sijk})^{-1}$. The ISP has been validated previously, revealing that it captures over $88 \%$ of all time-loss injuries that required medical attention.(10)

The rates provided in the manuscript are reported per 10,000 athlete exposures. We determined confidence intervals at $95 \%$ and identified p-values using a student t-test; values less than 0.05 were used to determine significance. We performed all statistical analyses using SAS Version 9.4 (Cary, North Carolina).

\section{Results}

\section{Rates of Injuries}

After appropriate weighting was applied, we identified 103,098 hand and wrist injuries in male and female sports of all NCAA divisions from 20042015. This corresponds to a rate of 5.33 injuries per 10,000 athlete events ( $95 \%$ Confidence Interval (Cl) $5.17,5.48)$ in all athletes in all divisions. The highest injury rate occurred in division I athletics, with a rate of 6.14 injuries per 10,000 athlete events $(5.79,6.48)$ compared to 4.17 injuries per 10,000 athlete events $(3.75,4.59)$ and 5.25 injuries per 10,000 athlete events $(4.93,5.57)$ in division II and division III athletics, respectively $(p<0.01)$. This trend was preserved in male and female student athletes. Male division I athletes sustained the highest rate of hand and wrist injuries with 7.05 per 10,000 athlete events $(6.62,7.49), 4.62$ per 10,000 athlete events $(4.08,5.17)$ in division II male athletes and 5.82 per 10,000 athlete events $(5.39,6.25)$ in division III male athletes $(\mathrm{p}<0.01)$. Female division I athletes similarly sustained the highest hand and wrist injuries at a rate of 4.47 per 10,000 athlete events $(3.90,5.04)$ compared to 3.38 injuries per 10,000 athlete events $(2.73,4.04)$ in division II female athletes and 4.26 injuries per 10,000 athlete events $(3.78,4.75)$ in division III female athletes $(p<0.01)$. We summarized this data in Table 1. 
Table 1

Total Hand and Wrist Injury Rate by Division and Gender

\begin{tabular}{|c|c|c|c|c|c|c|c|}
\hline Division & $\begin{array}{l}\text { Injury rate/10,000 athlete- } \\
\text { exposures }^{a}\end{array}$ & \multicolumn{2}{|c|}{$\begin{array}{l}\text { 95\% Confidence } \\
\text { Interval }\end{array}$} & OR (Between Divisions) & \multicolumn{2}{|c|}{ 95\% Confidence Interval } & P-value \\
\hline \multicolumn{8}{|l|}{ All sports } \\
\hline Division I & 6.14 & 5.79 & 6.48 & ref & ref & ref & ref \\
\hline Division II & 4.17 & 3.75 & 4.59 & 0.620 & 0.610 & 0.631 & $<0.01$ \\
\hline Division III & 5.25 & 4.93 & 5.57 & 0.786 & 0.775 & 0.797 & $<0.01$ \\
\hline All Divisions & 5.33 & 5.17 & 5.48 & - & - & - & - \\
\hline \multicolumn{8}{|l|}{ Men's sport } \\
\hline Division I & 7.05 & 6.62 & 7.49 & ref & ref & ref & ref \\
\hline Division II & 4.62 & 4.08 & 5.17 & 0.653 & 0.642 & 0.669 & $<0.01$ \\
\hline Division III & 5.82 & 5.39 & 6.25 & 0.825 & 0.811 & 0.839 & $<0.01$ \\
\hline All Divisions & 6.01 & 5.80 & 6.21 & - & - & - & - \\
\hline \multicolumn{8}{|l|}{$\begin{array}{l}\text { Womens } \\
\text { sports }\end{array}$} \\
\hline Division I & 4.47 & 3.90 & 5.04 & ref & ref & ref & ref \\
\hline Division II & 3.38 & 2.73 & 4.04 & 0.758 & 0.733 & 0.783 & $<0.01$ \\
\hline Division III & 4.26 & 3.78 & 4.75 & 0.954 & 0.923 & 0.980 & 0.01 \\
\hline All Divisions & 4.13 & 3.88 & 4.371 & - & - & - & - \\
\hline
\end{tabular}

a Athlete events include practice and competition

\section{Types Of Injuries}

The types of hand and wrist injuries sustained by collegiate athletes varied widely. The most common type of injury overall were ligamentous injuries of the phalanx and had an overall rate of 1.416 per 10,000 athlete events $(1.321,1.510), 1.724$ per 10,000 athlete events $(1.564,1.884)$ in division I, 0.930 per 10,000 athlete events $(0.760,1.099)$ in division II and 1.414 per 10,000 athlete events $(1.258,1.569)$ in division III. The second most common type of hand and wrist injuries identified were contusions involving the hand or finger, occurring at a rate of 0.770 per 10,000 athlete events $(0.688,0.852)$ in all divisions, 0.902 per 10,000 athlete events $(0.771,1.033)$ in division I, 0.595 per 10,000 athlete events $(0.411,0.779)$ in division II and 0.749 per 10,000 athlete events $(0.621,0.877)$ in division III. The most common fractures sustained among all NCAA divisions were metacarpal fractures at a rate of 0.507 per 10,000 athlete events $(0.452,0.561), 0.541$ per $10,000(0.451,0.631)$ in division I athletes, 0.513 per 10,000 athlete events $(0.383,0.643)$ in division II athletes and 0.470 per 10,00 athlete events $(0.395,0.544)$ per 10,000 athlete events in division III. We demonstrate the specific injuries for each division in Table 2. 
Table 2

Rates of Hand and Wrist Injuries by diagnosis

\begin{tabular}{|c|c|c|c|c|c|c|c|c|c|c|c|c|}
\hline & \multicolumn{3}{|l|}{ Overall } & \multicolumn{3}{|l|}{ Division I } & \multicolumn{3}{|l|}{ Division II } & \multicolumn{3}{|l|}{ Division III } \\
\hline & $\begin{array}{l}\text { Injury } \\
\text { rate/10,000 } \\
\text { athlete- } \\
\text { exposures }^{a}\end{array}$ & \multicolumn{2}{|c|}{$\begin{array}{l}95 \% \\
\text { Confidence } \\
\text { Interval }\end{array}$} & $\begin{array}{l}\text { Injury } \\
\text { rate/10,000 } \\
\text { athlete- } \\
\text { exposures }^{a}\end{array}$ & \multicolumn{2}{|c|}{$\begin{array}{l}95 \% \\
\text { Confidence } \\
\text { Interval }\end{array}$} & $\begin{array}{l}\text { Injury } \\
\text { rate/10,000 } \\
\text { athlete- } \\
\text { exposures }^{a}\end{array}$ & \multicolumn{2}{|c|}{$\begin{array}{l}95 \% \\
\text { Confidence } \\
\text { Interval }\end{array}$} & $\begin{array}{l}\text { Injury } \\
\text { rate/10,000 } \\
\text { athlete- } \\
\text { exposures }^{a}\end{array}$ & \multicolumn{2}{|c|}{$\begin{array}{l}95 \% \\
\text { Confidence } \\
\text { Interval }\end{array}$} \\
\hline $\begin{array}{l}\text { Dislocation - } \\
\text { Phalanx }\end{array}$ & 0.422 & 0.367 & 0.477 & 0.464 & 0.386 & 0.543 & 0.451 & 0.309 & 0.594 & 0.362 & 0.281 & 0.444 \\
\hline $\begin{array}{l}\text { Phalangeal } \\
\text { Fracture }\end{array}$ & 0.474 & 0.414 & 0.534 & 0.538 & 0.444 & 0.633 & 0.320 & 0.219 & 0.421 & 0.506 & 0.399 & 0.614 \\
\hline $\begin{array}{l}\text { Metacarpal } \\
\text { Fracture }\end{array}$ & 0.507 & 0.452 & 0.561 & 0.541 & 0.451 & 0.631 & 0.513 & 0.383 & 0.643 & 0.470 & 0.395 & 0.544 \\
\hline $\begin{array}{l}\text { Scaphoid } \\
\text { Fracture }\end{array}$ & 0.112 & 0.084 & 0.139 & 0.098 & 0.056 & 0.141 & 0.090 & 0.033 & 0.147 & 0.138 & 0.093 & 0.182 \\
\hline $\begin{array}{l}\text { Other Carpal } \\
\text { Fracture }\end{array}$ & 0.075 & 0.051 & 0.099 & 0.093 & 0.046 & 0.141 & 0.069 & 0.027 & 0.111 & 0.061 & 0.027 & 0.094 \\
\hline $\begin{array}{l}\text { Ligamentous } \\
\text { Injury - Other } \\
\text { Wrist Sprain }\end{array}$ & 0.691 & 0.620 & 0.761 & 0.799 & 0.692 & 0.906 & 0.386 & 0.273 & 0.499 & 0.772 & 0.640 & 0.904 \\
\hline $\begin{array}{l}\text { Ligamentous } \\
\text { Injury - } \\
\text { Phalanx }\end{array}$ & 1.416 & 1.321 & 1.510 & 1.724 & 1.564 & 1.884 & 0.930 & 0.760 & 1.099 & 1.414 & 1.258 & 1.569 \\
\hline $\begin{array}{l}\text { Ligamentous } \\
\text { Injury - TFCC, } \\
\text { DRUJ, } \\
\text { Scapholunate }\end{array}$ & 0.097 & 0.068 & 0.126 & 0.116 & 0.073 & 0.159 & 0.078 & 0.017 & 0.138 & 0.091 & 0.042 & 0.139 \\
\hline $\begin{array}{l}\text { Tendon - } \\
\text { Phalanx }\end{array}$ & 0.186 & 0.147 & 0.225 & 0.155 & 0.110 & 0.200 & 0.231 & 0.116 & 0.346 & 0.188 & 0.131 & 0.245 \\
\hline $\begin{array}{l}\text { Tendon - } \\
\text { Wrist }\end{array}$ & 0.109 & 0.082 & 0.136 & 0.119 & 0.076 & 0.162 & 0.118 & 0.057 & 0.180 & 0.094 & 0.053 & 0.136 \\
\hline $\begin{array}{l}\text { Contusion - } \\
\text { Hand/finger }\end{array}$ & 0.770 & 0.688 & 0.852 & 0.902 & 0.771 & 1.033 & 0.595 & 0.411 & 0.779 & 0.749 & 0.621 & 0.877 \\
\hline $\begin{array}{l}\text { Contusion - } \\
\text { Wrist }\end{array}$ & 0.156 & 0.124 & 0.188 & 0.207 & 0.144 & 0.269 & 0.094 & 0.034 & 0.154 & 0.144 & 0.100 & 0.189 \\
\hline Nailbed & 0.060 & 0.033 & 0.088 & 0.093 & 0.037 & 0.149 & 0.032 & -0.019 & 0.084 & 0.045 & 0.012 & 0.078 \\
\hline $\begin{array}{l}\text { Wrist } \\
\text { Tenosynovitis }\end{array}$ & 0.079 & 0.049 & 0.108 & 0.055 & 0.030 & 0.080 & 0.111 & 0.014 & 0.208 & 0.082 & 0.042 & 0.122 \\
\hline $\begin{array}{l}\text { Soft Tissue } \\
\text { Injury }\end{array}$ & 0.164 & 0.129 & 0.199 & 0.214 & 0.152 & 0.276 & 0.150 & 0.076 & 0.223 & 0.125 & 0.075 & 0.175 \\
\hline Infection & 0.010 & 0.003 & 0.017 & 0.018 & 0.004 & 0.032 & 0.000 & 0.000 & 0.000 & 0.009 & -0.002 & 0.021 \\
\hline
\end{tabular}

${ }^{\text {a }}$ Athlete events include practice and competition

\section{Management Of Hand And Wrist Injuries In Collegiate Athletes}

The majority of hand and wrist injuries were managed conservatively. Of all NCAA student athletes that sustained hand and wrist injuries between 2004 and $2015,3.78 \%$ underwent surgical treatment. A significantly higher percentage of division I student athletes (4.45\%) underwent surgical intervention for their hand and wrist injuries compared to division II (3.56\%) and division III (3.12\%) student athletes $(p<0.01)$. This pattern was consistent across male and female sports. Division I male student athletes with hand and wrist injuries underwent surgical intervention at a rate of $4.88 \%$, while $4.37 \%$ of division II male student athletes underwent surgery and $3.36 \%$ of division III male student athletes underwent surgical intervention $(p<0.01)$. For division I female student athletes that sustained hand and wrist injuries, $3.22 \%$ underwent surgical intervention, while $1.65 \%$ division II female student athletes and $2.57 \%$ division III female student athletes underwent operative treatment for their hand and wrist injuries ( $p<0.01)$. We summarize this data in Table 3. 
Table 3

Hand and Wrist Injuries Requiring Surgery

\begin{tabular}{|c|c|c|c|c|c|c|c|c|}
\hline \multirow{2}{*}{$\begin{array}{l}\text { Division } \\
\text { All Sports }\end{array}$} & \multirow[t]{2}{*}{$\begin{array}{l}\text { Injuries requiring } \\
\text { surgery (\%) }\end{array}$} & \multirow[t]{2}{*}{$\begin{array}{l}\text { Surgery Rate/ } 10,000 \text { athlete- } \\
\text { exposure }^{a}\end{array}$} & \multicolumn{2}{|c|}{$\begin{array}{l}95 \% \text { Confidence } \\
\text { Interval }\end{array}$} & \multirow[t]{2}{*}{$\begin{array}{l}\text { OR (Between } \\
\text { Divisions) }\end{array}$} & \multicolumn{2}{|c|}{$\begin{array}{l}\text { 95\% Confidence } \\
\text { Interval }\end{array}$} & \multirow[t]{2}{*}{$\begin{array}{l}P \text { - } \\
\text { value }\end{array}$} \\
\hline & & & & & & & & \\
\hline Division I & 4.45 & 0.273 & 0.245 & 0.301 & ref & & & \\
\hline Division II & 3.56 & 0.148 & 0.096 & 0.201 & 0.542 & 0.495 & 0.593 & $\begin{array}{l}< \\
0.01\end{array}$ \\
\hline Division III & 3.12 & 0.164 & 0.131 & 0.196 & 0.599 & 0.556 & 0.645 & $\begin{array}{l}< \\
0.01\end{array}$ \\
\hline All Divisions & 3.78 & 0.201 & 0.191 & 0.212 & - & & & \\
\hline \multicolumn{9}{|l|}{ Men's Sport } \\
\hline Division I & 4.88 & 0.344 & 0.306 & 0.383 & ref & & & \\
\hline Division II & 4.37 & 0.202 & 0.125 & 0.279 & 0.587 & 0.532 & 0.647 & $\dot{0} 01$ \\
\hline Division III & 3.36 & 0.195 & 0.153 & 0.238 & 0.567 & 0.521 & 0.617 & $\begin{array}{l}<.01 \\
0.01\end{array}$ \\
\hline All Divisions & 4.22 & 0.254 & 0.241 & 0.267 & - & & & \\
\hline \multicolumn{9}{|l|}{$\begin{array}{l}\text { Women's } \\
\text { Sports }\end{array}$} \\
\hline Division I & 3.22 & 0.144 & 0.107 & 0.181 & ref & & & \\
\hline Division II & 1.65 & 0.056 & 0.002 & 0.110 & 0.389 & 0.307 & 0.492 & $\begin{array}{l}<.01 \\
0.01\end{array}$ \\
\hline Division III & 2.57 & 0.109 & 0.060 & 0.159 & 0.761 & 0.649 & 0.892 & 0.01 \\
\hline All Divisions & 2.65 & 0.109 & 0.093 & 0.125 & - & & & \\
\hline
\end{tabular}

a Athlete events include practice and competition

\section{Mean Time Loss Following Hand And Wrist Injuries}

Most hand and wrist injuries sustained by NCAA athletes result in less than one day lost of athlete participation. The mean time lost among all collegiate athletes was 7.14 days $(6.02,8.25)$, with division I student athletes missing 6.29 days $(5.39,7.19)$, division II student athletes missing 7.96 days $(6.38,9.54)$ and division III student athletes missing 7.86 days $(5.09,10.62)$. Male division I student athletes missed the fewest number of days on average with a mean of 5.66 days $(4.79,6.52)$, male division II student athletes missed a mean of 8.37 days $(6.35,10.39)$ and male division III student athletes missed a mean of 8.99 days $(4.99,12.99)$ from their hand and wrist injuries. The trend was not consistent among female collegiate student athletes. Division I female student athletes missed a mean of 7.87 days $(5.57,10.18)$, while division II female student athletes missed a mean of 7.04 days $(4.62,9.47)$ and division III student athletes missed a mean of 5.39 days $(4.32,6.46)$. We summarized this data in Table 4 . 
Table 4

Mean Time-loss Following Total Hand and Wrist Injuries

Time Lost to Injury (\%)

\begin{tabular}{|c|c|c|c|c|c|c|c|c|c|}
\hline Sport & $\begin{array}{l}<1 \\
\text { day }\end{array}$ & $1-7$ days & $8-14$ days & $15-30$ days & $30-60$ days & $>60$ days & Mean Time Lost (Days) & \multicolumn{2}{|c|}{ 95\% Confidence Interval } \\
\hline \multicolumn{10}{|l|}{ All sports } \\
\hline Division I & 57.2 & 25.0 & 7.2 & 4.0 & 4.9 & 1.7 & 6.29 & 5.39 & 7.19 \\
\hline Division II & 44.3 & 32.2 & 7.7 & 7.2 & 7.5 & 1.1 & 7.96 & 6.38 & 9.54 \\
\hline Division III & 45.1 & 34.4 & 10.5 & 5.3 & 3.3 & 1.5 & 7.86 & 5.09 & 10.62 \\
\hline $\begin{array}{l}\text { All } \\
\text { Divisions }\end{array}$ & 50.5 & 29.7 & 8.5 & 5.0 & 4.8 & 1.5 & 7.14 & 6.02 & 8.25 \\
\hline \multicolumn{10}{|l|}{ Male sports } \\
\hline Division I & 59.2 & 23.7 & 6.8 & 3.6 & 5.2 & 1.5 & 5.66 & 4.79 & 6.52 \\
\hline Division II & 45.1 & 30.8 & 8.4 & 6.3 & 8.0 & 1.4 & 8.37 & 6.35 & 10.39 \\
\hline Division III & 46.1 & 33.2 & 9.8 & 5.9 & 3.4 & 1.7 & 8.99 & 4.99 & 12.99 \\
\hline All divisions & 52.0 & 28.4 & 8.2 & 4.9 & 5.0 & 1.6 & 7.29 & 5.78 & 8.80 \\
\hline \multicolumn{10}{|c|}{ Female sports } \\
\hline Division I & 52.2 & 28.2 & 8.0 & 5.1 & 4.2 & 2.3 & 7.87 & 5.57 & 10.18 \\
\hline Division II & 42.4 & 35.3 & 6.1 & 9.4 & 6.4 & 0.4 & 7.04 & 4.62 & 9.47 \\
\hline Division III & 49.1 & 33.1 & 10.8 & 3.4 & 2.7 & 0.9 & 5.39 & 4.32 & 6.46 \\
\hline All divisions & 46.9 & 32.8 & 9.2 & 5.4 & 4.1 & 1.5 & 6.79 & 5.61 & 7.97 \\
\hline
\end{tabular}

\section{Discussion}

This study demonstrates the burden of hand and wrist injuries on NCAA student athletes distributed among the athletic divisions. Many of these injuries are minor and can be managed conservatively, though more severe injuries require surgical intervention and incur significant time away from participation in the sport. Hand and wrist injuries are more likely to occur during competition as compared to practice due to the increased intensity and the less controlled environment.(6-8) The hand and wrist injury rates were significantly higher for division I student athletes compared to the other divisions. Male and female division I student athletes sustained significantly higher incidence of hand and wrist injuries compared to athletes in divisions II and III, which could be attributed to the higher intensity of division I sports. While our study cannot prove these differences in intensity, it is generally accepted that there is an increasing level of skill, athletic training, and time investment in the sport as one progresses to a higher division of play. However, this assumption does not explain the higher injury rate for division III compared to division II. Interestingly, other studies using the ISP database have revealed a similar pattern of higher injury rates in division III vs. other divisions.(12-15) This could be explained by differences in athleticism and skill such that division III athletes could lag behind in these traits compared to division I and II athletes, placing themselves and other athletes at greater risk for injury.(12) Furthermore, division III programs may trail the other divisions in available resources and coaching experience that could be directed towards improved strength, conditioning, and injury prevention programs.(13)

The NCAA student athlete spends approximately 40 hours per week, or the same amount of time as a full-time job, participating in their sport during practice and competition. The motivation for this dedication varies by the student athlete. When an injury occurs, this may be devastating to the team and to the student athlete. Narratives of victory on the playing field, respect for toughness and sacrifice and the redemptive value of athletic participation are motivating factors to return to play following an injury.(9) As we hypothesized, division I student athletes tended to miss fewer days compared to division II and III student athletes. This trend remained true in male athletes, where division I male student athletes returned to their sport approximately three days faster than their division II and division III counterparts. Interestingly for female student athletes, division III female student athletes missed the fewest days from participation in their sport. Due to the nature of the dataset, we are unable to analyze particular causality of the hand and wrist injuries. The decision for a player to miss more time may vary based on the player position or the time of competition within the season. Contact sports, including ice hockey, football, volleyball, lacrosse, basketball, and field hockey, have higher rates of hand and wrist injuries in NCAA sports and are generally evenly accessible for both genders; this would not explain the discrepancy in time loss injuries between division I male and female student athletes.(6)

The NCAA is committed to the safety of its student athletes. In order to reduce injury rates, the Sports Science Institute and the College Athletic Trainers' Society have recommended eliminating twice daily practices and limiting the number of live practices during the preseason to 3 per 7-day period.(16) In general, these societies are working to reduce player-on-player contact to make collegiate athletics safer. While only speculative, such efforts to reduce injuries may be exemplified by the difference between the rate of hand and wrist injuries in NCAA athletes and the general population. Approximately 
$25 \%$ of all sports-related injuries in NCAA athletes involve the hand and wrist, $(2,3)$ while $47 \%$ of acute sporting injuries in the general population involved the hand and wrist.(4)

Time away from athletic participation due to injury can negatively affect the student athlete as well as the team dynamic. Most hand and wrist injuries can be treated conservatively, requiring time missed from athletics. Fifty percent of all hand and wrist injuries sustained by male and female NCAA student athletes required less than one day away from the respective sport. At the same time, approximately $1 \%-2 \%$ of all hand and wrist injuries across male and female athletics result in a loss of greater than 60 days away from their sport. Some sports have limited seasons that last only a few months, such as basketball or hockey. Any loss of time will alter team dynamics and can dramatically affect the outcome of a season. Hand and wrist injuries that cause student athletes to miss more than one day can dramatically affect a team and an entire season.

More severe injuries to the hand and wrist require surgical intervention. We hypothesized that division I student athletes, those playing at the highest collegiate level, would have higher rates of surgical intervention for their hand and wrist injuries. While the surgical intervention rate is relatively low at $3.65 \%$ across all genders and divisions, we found a statistically significant increased surgical intervention rate in division I student athletes compared to division II and division III athletes. This difference was more apparent when evaluating the different surgical intervention rates in male and female student athletes such that male student athletes had higher rates of surgical intervention compared to female student athletes across all divisions. It is possible that differences in surgical rates could suggest variability among treating hand surgeons regarding management of common sports-related hand and wrist injuries in collegiate student athletes. A study polled 37 consultant hand surgeons for teams in the National Football League (NFL), the National Basketball Association (NBA) and Major League Baseball (MLB). The surgeons completed a survey regarding the management of ten common hand injuries and there was variability in their responses regarding initial management, return to protected play and return to unprotected play.(17) These variances are likely due to differences in injury, player position, time of year within the season, or surgeon preference. However, it is difficult to elicit these differences in the NCAA-ISP database because these variables are not reported.

There are several limitations of this study. Because we examined sports injuries collected in the NCAA-ISP database, our findings may not be generalizable to other sports or non-collegiate level athletics. We did not separate athletes based on which sport they played, nor by seniority, pre-, regular or post-season activity, player position or by playing surface. We did not look at specific injury mechanisms. When reporting the types of injuries sustained, we chose to present the general categories of injuries rather than the details of each fracture (e.g. 1st vs. 5th metacarpal fracture) or ligamentous injury (e.g. ulnar collateral ligament injury) as we felt this would provide a level of granularity that is beyond the scope of this manuscript. The data reported is from the NCAA-ISP database, which is based on voluntary reports from athletic trainers. This manner of data collection is vulnerable to reporting bias because we can't definitively conclude that each injury was accurately reported, however, our large sample size would help mitigate this bias. While this will continue to be a limitation for studies using this dataset, validation studies show that the NCAA-ISP captured $88.3 \%$ of all time-lost events across all divisions $(10,18)$; this was then integrated into the weighting of the data provided by the ISP.(10) While using both eras of the dataset allowed us to increase our sample size, it should be noted that non-time-loss injuries were not recorded until the later era beginning in 2009 . This change in data recording methodology affected all sports and divisions thus should not impact our general findings. In the future, we would like to evaluate hand and wrist injury rates in collegiate athletes over time to see if they are reduced, as the focus of the NCAA is on student athlete safety. It would also be interesting to look at surgical intervention rates over time in NCAA student athletes. Surgeons have become more aggressive about pursuing surgical management of hand and wrist injuries in some sports. In NCAA football in $2008,6 \%$ of UCL injuries to the thumb underwent surgical intervention; in 2016, 10\% were treated surgically.(8) The focus should be on individualized treatment of collegiate athletes, emphasizing student athlete safety and preventing long-term complications. This is always kept in balance by the amount of time away from athletics, as days lost can have a significant impact on student athlete and team performance.

\section{Conclusion}

Hand and wrist injuries are common among collegiate athletes. Many of these injuries are minor, but severe injuries require surgery and incur significant time away from athletics. NCAA division I athletes tend to be injured more than divisions II and III, with fewer missed days in male student athletes, and a higher overall surgical intervention rate. Further studies investigating the role of individual sports, player position, specific injury patterns and change in management over time are indicated.

\section{Abbreviations}

$\mathrm{AE}$

Athlete-exposure

$\mathrm{Cl}$

Confidence Interval

DRUJ

Distal radioulnar joint

ISP

Injury Surveillance Program

NCAA

National Collegiate Athletic Association 
NCAA-ISP

National Collegiate Athletic Association Injury Surveillance Program

NTL

Non-time loss

TL

Time loss

TFCC

Triangular fibrocartilaginous complex

\section{Declarations}

Ethics approval and consent to participate: Not applicable

Consent for publication: Not Applicable

Availability of data and material: The NCAA Injury Surveillance Program data used in this study were provided by the Datalys Center for Sports Injury Research and Prevention

Competing interests: The authors declare that they have no competing interests

Funding: The NCAA Injury Surveillance Program was funded by the NCAA and the data in this program were provided by the Datalys Center for Sports Injury Research and Prevention

\section{Authors' contributions:}

$\mathrm{KH}$ : Conception and design of the work, analysis, interpretation of data, drafted and revised the work

DD: Acquisition, analysis, and interpretation of data, drafted the work and substantively revised the work

DM: Analysis and interpretation of data, drafted and substantively revised the work

AS: Analysis and interpretation of data, and drafted the work

JA: Conception and design of the work, substantively revised it

All authors approved the submitted version of this manuscript and agree to be personally accountable for their own contributions.

\section{Acknowledgements}

This publication contains materials created, compiled or produced by the Datalys Center for Sports Injury Research and Prevention, Inc. on behalf of the National Collegiate Athletic Association ( . All rights reserved. The NCAA Injury Surveillance Program data were provided by the Datalys Center for Sports Injury Research and Prevention. The Injury Surveillance Program (ISP) was funded by the National College Athletic Association (NCAA). The content of this manuscript is solely the responsibility of the authors and does not necessarily represent the official views of the Datalys Center or the NCAA. We thank the many athletic trainers who have volunteered their time and efforts to submit data to the NCAA-ISP. Their efforts are greatly appreciated and have had a tremendously positive effect on the safety of collegiate student athletes.

\section{References}

1. Irick E. Ncaa sports sponshorship and participation rates report: 2015-2016. 2016. http://www.ncaapublications.com/productdownloads/PR1516.pdf. 22 Apr 2018.

2. Amadio PC. Epidemiology of hand and wrist injuries in sports. Hand Clin. 1990;6(3):379-81.

3. Avery DM 3rd, Rodner CM, Edgar CM. Sports-related wrist and hand injuries: A review. J Orthop Surg Res. 2016;11(1):99.

4. Simpson D, McQueen MM. Acute sporting injuries to the hand and wrist in the general population. Scott Med J. 2006;51(2):25-6.

5. NCAA. Health and safety 2018. http://www.ncaa.org/health-and-safety. 22 Apr 2018.

6. Simpson AM, Donato DP, Veith J, Magno-Padron D, Agarwal JP. Hand and wrist injuries among collegiate athletes: The role of sex and competition on injury rates and severity. Orthop J Sports Med. 2020;8(12):2325967120964622.

7. Bartels DW, Hevesi M, Wyles C, Macalena J, Kakar S, Krych AJ. Epidemiology of hand and wrist injuries in ncaa men's football: 2009-2010 to 2013-2014. Orthop J Sports Med. 2019;7(4):2325967119835375.

8. Carver TJ, Schrock JB, Kraeutler MJ, McCarty EC. The evolving treatment patterns of ncaa division i football players by orthopaedic team physicians over the past decade, 2008-2016. Sports Health. 2018;10(3):234-43. 
9. Corman SR, Adame BJ, Tsai JY, Ruston SW, Beaumont JS, Kamrath JK, et al. Socioecological influences on concussion reporting by ncaa division 1 athletes in high-risk sports. PLoS One. 2019;14(5):e0215424.

10. Kerr ZY, Dompier TP, Snook EM, Marshall SW, Klossner D, Hainline B, et al. National collegiate athletic association injury surveillance system: Review of methods for 2004-2005 through 2013-2014 data collection. J Athl Train. 2014;49(4):552-60.

11. Chorney SR, Sobin L, Goyal P, Suryadevara AC. Maxillofacial injuries among national collegiate athletic association athletes: $2004-2014$. Laryngoscope. 2017;127(6):1296-301.

12. Clifton DR, Onate JA, Hertel J, Pierpoint LA, Currie DW, Wasserman EB, et al. The first decade of web-based sports injury surveillance: Descriptive epidemiology of injuries in us high school boys' basketball (2005-2006 through 2013-2014) and national collegiate athletic association men's basketball (2004-2005 through 2013-2014). J Athl Train. 2018;53(11):1025-36.

13. Kerr ZY, Putukian M, Chang CJ, DiStefano LJ, Currie DW, Pierpoint LA, et al. The first decade of web-based sports injury surveillance: Descriptive epidemiology of injuries in us high school boys' soccer (2005-2006 through 2013-2014) and national collegiate athletic association men's soccer (2004-2005 through 2013-2014). J Athl Train. 2018;53(9):893-905.

14. Kerr ZY, Wilkerson GB, Caswell SV, Currie DW, Pierpoint LA, Wasserman EB, et al. The first decade of web-based sports injury surveillance: Descriptive epidemiology of injuries in united states high school football (2005-2006 through 2013-2014) and national collegiate athletic association football (2004-2005 through 2013-2014). J Athl Train. 2018;53(8):738-51.

15. Pierpoint LA, Lincoln AE, Walker N, Caswell SV, Currie DW, Knowles SB, et al. The first decade of web-based sports injury surveillance: Descriptive epidemiology of injuries in us high school boys' lacrosse (2008-2009 through 2013-2014) and national collegiate athletic association men's lacrosse (2004-2005 through 2013-2014). J Athl Train. 2019;54(1):30-41.

16. Institute NSS. Safety in college football summit. 2016.

17. Dy CJ, Khmelnitskaya E, Hearns KA, Carlson MG. Opinions regarding the management of hand and wrist injuries in elite athletes. Orthopedics. 2013;36(6):815-9.

18. Kucera KL, Marshall SW, Bell DR, DiStefano MJ, Goerger CP, Oyama S. Validity of soccer injury data from the national collegiate athletic association's injury surveillance system. J Athl Train. 2011;46(5):489-99. 